ЕЛЕКТРИФІКАЦІЯ ТА АВТОМАТИЗАЦІЯ ГІРНИЧИХ РОБІТ

УДК 621.311

DOI: 10.20535/2079-5688.2017.32.86495

V.S. Stepashko, doctor of technical sciences, professor, A.R. Trachuk, postgraduate (Igor Sikorsky Kyiv Polytechnic Institute)

\title{
METHODOLOGY OF ANALYSIS AND FORECASTING OF THE ELECTRICITY CONSUMPTION IN UKRAINE BY USING THE GROUP METHOD OF DATA HANDLING
}

B.C. Степашко, докт. техн. наук, професор, А.Р. Трачук, аспірант (КПІ ім. Ігоря Сікорського)

\section{МЕТОДОЛОГІЯ АНАЛІЗУ ТА ПОБУДОВИ ПРОГНОЗНИХ МОДЕЛЕЙ СПОЖИВАННЯ ЕЛЕКТРОЕНЕРГІЇ В УКРАЇНІ ШЛЯХОМ ВИКОРИСТАННЯ МЕТОДУ ГРУПОВОГО УРАХУВАННЯ АРГУМЕНТІВ}

Considered issues of electricity consumption in Ukraine. The dynamics of energy consumption and the proposed guidelines gait efficient use of electricity. Researched and projected scenarios projected electricity consumption in general throughout Ukraine.

Keywords: energy balance; energy conservation; energy efficiency; energy statistics.

Розглянуті проблемні питання споживання електроенергї по Україні. Проаналізовано динаміку споживання електроенергї та запропоновані методичні рекомендачії ходо ефективного використання електроенергії. Досліджені та прогнозовані прогнозні сценаріі споживання електроенергії загалом по всій Україні.

Ключові слова: енергетичний баланс; енергозбереження; енергоефективність; енергетична статистика.

Рассмотрены проблемные вопросы потребления электроэнергии по Украине. Проанализирована динамика потребления электроэнергии и предложены методические рекомендации походкой эффективного использования электроэнергии. Исследовань $u$ спрогнозированные прогнозные сиенарии потребления электроэнергии в целом по всей Украине.

Ключевые слова: энергетический баланс; энергосбережение; энергоэффективность; энергетическая статистика.

Introduction. The basic foundation of the formation of the Ukraine grid construction is forecasting scenarios for different types of energy and the various criteria for effective use of energy resources. The problem of efficient use of energy resources raises crucial for sustainable economic development against the backdrop of energy saving national economy depends on energy imports, on the one hand, and rising prices for these resources. The solution to this problem is not only with 
ensuring energy security, but also with the level of development of regions and the quality of life of its population.

Forecasting electricity consumption in Ukraine today is an extremely important issue of strategic importance since conducted through analysis and building predictive models will be possible to develop guidelines for the efficient production and consumption across Ukraine as a whole.

Aim of the work is development of methodical provisions for forecasting electricity consumption in Ukraine through the use of group method of data handling.

Statement of material and research results. The level of energy has a decisive impact on the economy of the state, resolving social problems and living standards of citizens. Changes in energy prices immediately reflected in all industries, and the rest, the price of the final product. Therefore, instead of quantitative objectives of energy development, which was followed by Ukraine's economy in recent decades, energy has to go to power sustainable economic development, focused on that now developed countries. The said research leads scientists to balance the energy balance of Ukraine, which determined the relevance of the work. In the traditional understanding of energy balance is the ratio between the extraction (production) and consumption of different types of energy resources.

At the heart of the development of fuel and energy balance is a set of strategic statements of economic development, the definition of forecast volumes of energy consumption, based on adopted policies to increase energy efficiency, the development of fuel and energy complex and evaluating opportunities extraction and production of fuel and energy, as well as the formation of areas of import- exporting policy and determine the volume of purchase and sale of energy.

One of the mathematical methods of forecasting is group method of data handling, which allows you to build adequate predictive models of energy consumption in the system of Ukraine's energy balance.

With the help of a group of data handling and by using modern software were built predictive models of consumer energy resources in the system of energy balance of Ukraine:

1. Expected system model prediction for next year depends on the values of the previous year, offset $(-1)$ :

$$
\begin{aligned}
& \mathrm{Y} 1=89,726+0 * \mathrm{Y} 1(-1)-12,174 * \mathrm{Y} 2(-1)+0 * \mathrm{Y} 3(-1) \\
& \mathrm{Y} 2=0,3592+0 * \mathrm{Y} 1(-1)+0 * \mathrm{Y} 2(-1)+1,3623 * \mathrm{Y} 3 \\
& \mathrm{Y} 3=0,0000+0 * \mathrm{Y} 1(-1)+0 * \mathrm{Y} 2(-1)+1.0149 * \mathrm{Y} 3(-1)
\end{aligned}
$$

Comment: Y1 (final consumption of energy (FCE)) Depends on Y2 (-1) (last year) and Y2 (primary energy intensity (total primary energy supply, t.o.e. / $€ 1000$ GDP)) in turn from Y3 (-1) last year - that Y1 and Y2 contain auto regressive components; This model is for purely autoregressive Y3: Y3 (final energy consumption (final energy consumption toe / $€ 1000$ GDP)) depends on its previous value Y3 (-1).

Initial data for forecasting final energy consumption are presented in Table 1 
Output consumption of final energy consumption

\begin{tabular}{|c|c|c|c|}
\hline Year & $\begin{array}{c}\text { Final consumption } \\
\text { of energy (FCE) } \\
\text { thousand. t.o.e. }\end{array}$ & $\begin{array}{c}\text { Primary energy intensity } \\
\text { (total primary energy } \\
\text { supply, t.o.e. } / € 1000 \\
\text { GDP) }\end{array}$ & $\begin{array}{c}\text { Final energy } \\
\text { consumption (final } \\
\text { energy consumption } \\
\text { t.o.e. / } € 1000 \text { GDP) }\end{array}$ \\
\cline { 2 - 4 } & Y1 & Y2 & Y3 \\
\hline 2006 & 72,948 & 1,518 & 0,822 \\
\hline 2007 & 73,270 & 1,281 & 0,691 \\
\hline 2008 & 73,846 & 1,091 & 0,616 \\
\hline 2009 & 74,037 & 1,363 & 0,753 \\
\hline 2010 & 74,238 & 1,429 & 0,796 \\
\hline 2011 & 74,303 & 1,497 & 0,842 \\
\hline 2012 & 74,067 & 1,524 & 0,879 \\
\hline 2013 & 75,984 & 1,582 & 0,895 \\
\hline 2014 & 63,266 & 1,620 & 0,921 \\
\hline 2015 & 67,425 & 1,675 & 0,948 \\
\hline
\end{tabular}

Results of approximation and forecast FCE for the next 5 years:

1. The first indicator Y1 (final energy consumption) is given in tab. 2

Table 2

Prediction of final consumption of energy (FCE) thousand t.o.e.

by using the group method of data handling

\begin{tabular}{|c|l|l|l|l|l|l|l|l|l|}
\hline Year & 2006 & 2007 & 2008 & 2009 & 2010 & 2011 & 2012 & 2013 & 2014 \\
\hline Table & 72,948 & 73,270 & 73,846 & 74,037 & 74,238 & 74,303 & 74,067 & 75,984 & 63,266 \\
\hline Model & & 71,247 & 71,721 & 71,518 & 71,312 & 71,104 & 70,892 & 70,677 & 70,458 \\
\hline
\end{tabular}

Continuation of Table 2

\begin{tabular}{|c|l|l|l|l|l|l|}
\hline Year & 2015 & 2016 & 2017 & 2018 & 2019 & 2020 \\
\hline Table & 67,425 & & & & & \\
\hline Model & 70,237 & 69,335 & 69,632 & 69,398 & 69,160 & 68,919 \\
\hline
\end{tabular}

2. The second indicator Y2 - Primary energy intensity (total primary energy supply, t.o.e. / $€ 1000$ GDP) is given in tab. 3

Table 3

Prediction of primary energy intensity by using the group method of data handling

\begin{tabular}{|c|l|l|l|l|l|l|l|l|l|}
\hline Year & 2006 & 2007 & 2008 & 2009 & 2010 & 2011 & 2012 & 2013 & 2014 \\
\hline Table & 1,518 & 1,281 & 1,091 & 1,363 & 1,429 & 1,497 & 1,524 & 1,582 & 1,620 \\
\hline Model & & 1,48 & 1,50 & 1,51 & 1,53 & 1,55 & 1,56 & 1,58 & 1,60 \\
\hline
\end{tabular}

Continuation of Table 3

\begin{tabular}{|c|l|l|l|l|l|l|}
\hline Year & 2015 & 2016 & 2017 & 2018 & 2019 & 2020 \\
\hline Table & 1,675 & & & & & \\
\hline Model & 1,62 & 1,651 & 1,670 & 1,709 & 1,689 & 1,729 \\
\hline
\end{tabular}


3. The third indicator $\mathrm{Y} 3$ (final energy consumption (final energy consumption t.o.e. $/ € 1000$ GDP) are shown in tab. 4

Table 4

Prediction of final energy intensity (final energy consumption t.o.e. / € 1000 GDP) by using the group method of data handling

\begin{tabular}{|c|l|l|l|l|l|l|l|l|l|}
\hline Year & 2006 & 2007 & 2008 & 2009 & 2010 & 2011 & 2012 & 2013 & 2014 \\
\hline Table & 0,822 & 0,691 & 0,616 & 0,753 & 0,796 & 0,842 & 0,879 & 0,895 & 0,921 \\
\hline Model & & 0,83 & 0,85 & 0,86 & 0,87 & 0,88 & 0,90 & 0,91 & 0,93 \\
\hline
\end{tabular}

Continuation of Table 4

\begin{tabular}{|c|l|l|l|l|l|l|}
\hline Year & 2015 & 2016 & 2017 & 2018 & 2019 & 2020 \\
\hline Table & 0,948 & & & & & \\
\hline Model & 0,94 & 0,962 & 0,991 & 0,976 & 1,006 & 1,021 \\
\hline
\end{tabular}

Predictive System Model of FEC forecast for next year depends on the values of the last and before last year, offset (-1) and (-2)):

$$
\begin{gathered}
\mathrm{Y} 1=39,222+0,2496 * \mathrm{Y} 1(-1)+0 * \mathrm{Y} 1(-2)-29,210 * \mathrm{Y} 2(-1)+ \\
178,642 * \mathrm{Y} 2(-2)+0 * \mathrm{Y} 3(-1)-354,418^{*} \mathrm{Y} 3(-2) \\
\mathrm{Y} 2=0,0000+0 * \mathrm{Y} 1(-1)+0 * \mathrm{Y} 1(-2)+1,0316^{*} \mathrm{Y} 2(-1)+ \\
0 * \mathrm{Y} 2(-2)+0 * \mathrm{Y} 3(-1)+0 * \mathrm{Y} 3(-2) \\
\mathrm{Y} 3=0,0000+0 * \mathrm{Y} 1(-1)+0 * \mathrm{Y} 1(-2)+0,6410 * \mathrm{Y} 2(-1) \\
-0,0590 * \mathrm{Y} 2(-2)+1.0149 * \mathrm{Y} 3(-1)+0 * \mathrm{Y} 3(-2)
\end{gathered}
$$

Comment: Y1 depends on Y1 (-1), Y2 (-1), Y2 (-2) and Y3 (-2); Model is purely autoregressive $\mathrm{Y} 2$ : $\mathrm{Y} 2$ depends on its previous value $\mathrm{Y} 2(-1)$; $\mathrm{Y} 3$ depends on $\mathrm{Y} 2(-1)$, Y2 (-2) and Y3 (-1)

$$
\text { Forecasted balance of Electricity }
$$

$$
\begin{gathered}
\mathrm{Y} 1=0.3428 * \mathrm{Y} 1(-1)+0.722 * \mathrm{Y} 2(-1)+0.7087 * \mathrm{Y} 3(-1) \\
\mathrm{Y} 2=0.3942 * \mathrm{Y} 1(-1)+0.5874 * \mathrm{Y} 2(-1) \\
\mathrm{Y} 3=-11.4467+0.0847 * \mathrm{Y} 1(-1)+0.6787 * \mathrm{Y} 3(-1)
\end{gathered}
$$

Forecasting electricity consumption (gross) by using the group method of data handling are given in tab. 5

Table 5

Prediction of electricity consumption (gross) by using the group method of data handling:

\begin{tabular}{|c|l|l|l|l|l|l|l|l|l|}
\hline Year & 2006 & 2007 & 2008 & 2009 & 2010 & 2011 & 2012 & 2013 & 2014 \\
\hline Table & 177.9 & 183.7 & 193.7 & 198.8 & 204.7 & 209.5 & 216.9 & 226.9 & 231 \\
\hline Model & & 181.6 & 186.8 & 192.3 & 198.2 & 204.6 & 211.4 & 218.7 & 226.6 \\
\hline
\end{tabular}




\begin{tabular}{|c|l|l|l|l|l|l|}
\hline Year & 2015 & 2016 & 2017 & 2018 & 2019 & 2020 \\
\hline Table & & & & & & \\
\hline Model & 235.1 & 243.9 & 253.2 & 263.7 & 275 & 287.2 \\
\hline
\end{tabular}

Prediction of electricity consumption (net) by using the group method of data handling are given in tab. 6

Table 6

Prediction of electricity consumption (net) by using the group method of of data handling:

\begin{tabular}{|c|l|l|l|l|l|l|l|l|l|}
\hline Year & 2006 & 2007 & 2008 & 2009 & 2010 & 2011 & 2012 & 2013 & 2014 \\
\hline Table & 158.6 & 162.6 & 167.4 & 172.8 & 175.6 & 181.5 & 184.2 & 189.4 & 198.5 \\
\hline Model & & 163.3 & 167.5 & 172. & 176.9 & 182 & 187 & 193.5 & 199.9 \\
\hline
\end{tabular}

Continuation of Table 6

\begin{tabular}{|c|l|l|l|l|l|l|}
\hline Year & 2015 & 2016 & 2017 & 2018 & 2019 & 2020 \\
\hline Table & 208.5 & & & & & \\
\hline Model & 206.7 & 213.5 & 221.6 & 230 & 239 & 248.8 \\
\hline
\end{tabular}

Prediction of electricity export by the group method of data handling are given in tab. 6

Table 7

Prediction of electricity export by the group method of data handling:

\begin{tabular}{|c|l|l|l|l|l|l|l|l|l|}
\hline Year & 2006 & 2007 & 2008 & 2009 & 2010 & 2011 & 2012 & 2013 & 2014 \\
\hline Table & 8.56 & 9.35 & 10.47 & 10.86 & 11.35 & 13.65 & 15.33 & 17.37 & 19.23 \\
\hline Model & & 9.43 & 10.33 & 11.39 & 12.57 & 13.88 & 15.3 & 16.84 & 18.51 \\
\hline
\end{tabular}

Continuation of Table 7

\begin{tabular}{|c|l|l|l|l|l|l|}
\hline Year & 2015 & 2016 & 2017 & 2018 & 2019 & 2020 \\
\hline Table & 20 & & & & & \\
\hline Model & 20.31 & 21.69 & 23.94 & 26.24 & 28.7 & 31.33 \\
\hline
\end{tabular}

Prediction of energy consumption by using the group method of data handling:

$$
\begin{gathered}
\mathrm{Y} 1=88.6897-2.0492 * \mathrm{Y} 3(-1) \\
\mathrm{Y} 2=0.0823 * \mathrm{Y} 1(-1)-3.4666 * \mathrm{Y} 2(-1)+7.2614 * \mathrm{Y} 3(-1) \\
\mathrm{Y} 3=4.2195-2.2605 * \mathrm{Y} 2(-1)+4.5343 * \mathrm{Y} 3(-1)
\end{gathered}
$$

\section{Conclusions}

Through analysis of the dynamics of electricity consumption in Ukraine and analysis of such important indicators as the final energy consumption, primary energy consumption, the export of electricity consumption (net) electricity consumption 
(gross) final consumption of energy - were built predictive models in the energy sector through the use group method of data handling for the above indicators and made the following results:

- predicted the increase of final energy intensity from 8.22 t.n.e. / $€ 1000$ of GDP in 2005 to 9,52 t.n.e. / $€ 1000$ of GDP in 2020;

- predicted the increase of primary energy intensity from 15,18 t.n.e. $/ € 1000$ of GDP in 2005 to 16.74 t.n.e. / $€ 1,000$ of GDP in 2020;

- predicted the increase electricity exports from 8,56 in 2005 to 31,33 in 2020;

- predicted the growth of electricity consumption (net) from 158,6 in 2005 to 258,8 in 2020;

- predicted the growth of electricity consumption (gross) from 177,9 in 2005 to 287,2 in 2020 ;

- predicted the reduction of final consumption of electricity (FCE) from 72.95 thousand t.o.e. in 2005 to 68,91 thousand t.o.e. in 2020 .

\section{References}

1. Yvahnenko, A.G. Adoption decisions based on self-organization [Text] / A.G. Yvahnenko, Y.P. Zaichenko, V.D. Dimitrov. - M.: "Soviet Radio", 1976. - 280 p.

2. Kravets, I.O. Research methods of statistical and predictive analysis for autoregressive models [Text] / I.A. Kravets, G.A. Afanasyeva; Scientific Papers: Scientific-methodical journal. - Mykolaiv: CSU named after Petro Mohyla, 2009. Vol. 93.

3. Tatarkyn, A.I. The economic security of the region: the unity of theory, research methodology and practice [Text] / Tatarkyn A.I., Kuklin A.A., Romanov A.A., Chukanov V.N., Yakovlev V.I., Kozytsyn A.A. - Ekaterinburg: Publisher Ural. 2007. - 240 p.

4. Savenko, J.N. Energy balance [Text] / Y.N. Savenko, E.O. Steinways; Some questions of theory and practice. - M.: Energy, 2011. - 184 p.

5. Egorov, A.L. Method of analysis and energy balances of industrial enterprises [Text] / A.L. Egorov - St. Petersburg, 2012. - 134 p.

Стаття надійшла до редакиї 16.12.2016 p. 